\title{
USO DA PAPAÍNA NOS CURATIVOS FEITOS PELA ENFERMAGEM
}

Lina Monetta*

\begin{abstract}
RESUMO. São apresentados os resultados obtidos com o uso da papaína em escaras e soluções de continuidade de outras etiologias. Mostra a ação bioquímica da papaína, as facilidades do seu uso e descreve desde sua experiência com o uso do mamão em lesões de pele e escaras, até a implantação de um curativo com papaína em dois importantes hospitais de São Paulo.
\end{abstract}

\begin{abstract}
The research describes the results obtained with the use of papain on bed sores and wounds of other etiologies. The author thells about the papain biochemical action, how easy is its use and describes her experience with the use of papaya on skin lesion and bed sores, as so as the implementation of a routine of dressing with papain in two important hospitals in São Paulo - Brazil.
\end{abstract}

\section{INTRODUC̣ÃO}

À enfermeira é comumente delegada a tarefa de escolher o tratamento mais eficaz para a cicatrização de lesões de pele de vários tipos, desde leves dermatites de contato até profundas úlceras de decúbito.

Para essa escolha, ela deve, primeiramente, fazer uma análise do paciente, verificando principalmente os fatores individuais que interferem diretamente na cicatrização (idade, estado nutricional, presença de patologia e suas características), seguida de uma análise completa da lesão em questão (sua etiologia, comprometimento tecidual, fatores agravantes, complicações e possíveis seqüelas).

Existe, atualmente, em todo o mundo, forte tendência ao aproveitamento de recursos naturais na terapêutica e principalmente aqueles já utilizados, de há muito, pela medicina tradicional.

Dentre as muitas recomendações da Organização Mundial de Saúde (OMS, 1977) há a de se fazer investigação sobre sistemas de medicina tradicional, principalmente trabalhos para identificação de remédios eficazes de origem mineral, vegetal ou animal (OMS 1977).

Há muito que tribos da América, África e das Ilhas do Caribe utilizam o mamão verde, (Carica papaya) no tratamento de ferimentos. (MAMÃO, 1977; WISEMAN, 1980).

Segundo estudiosos do assunto, o mamão possui propriedades nutricionais e curativas excelentes. $\mathrm{Ri}$ co em vitaminas $\mathrm{A}, \mathrm{B}^{1}, \mathrm{~B}^{2}, \mathrm{~B}^{6}, \mathrm{C}$ e sais minerais como $\mathrm{Ca}, \mathrm{P}$ e Fe. Possui em seu látex, presente apenas na fruta verde, grandes quantidades de uma enzima proteolítica, a papaína. (BALBACHAS, s.d.).

Em 1968, Vinson foi o primeiro a estudar o princípio digestivo do látex do mamão ao qual denominara "caricina". Peckolt, em 1876, isolou esse princípio ativo denominando-o "papaiotina". Somente em 1879, Wurtz \& Bouchut publicaram um trabalho sobre o fermento digestivo do mamoeiro ao qual denominaram papaína, termo que vigora internacionalmente até hoje. (MEDINA et alii, 1980).

A papaína é uma mistura complexa de enzimas proteolíticas e peroxidases existentes no látex do mamoeiro, conhecido popularmente como "leite de mamão".

Segundo MEDINA et alii (1980), a papaína se caracteriza pela propriedade de provocar, em doses diminutas, a proteólise, isto é, a dissociação de uma quantidade importante de proteínas em moléculas mais simples e, finalmente, em aminoácidos.

No comércio, a papaína é apresentada sob a forma de um pó que varia do branco ao bege amarelado, com odor característico e leve sabor de pepsina. É solúvel em água e glicerol e, praticamente, insolúvel em álcool, éter e clorofórmio. (MARTINDALE, 1982).

Sua atividade proteolítica sofre influência do $\mathrm{pH}$ $(\mathrm{pH}$ ótimo $=5$ à 8$)$. É inativada ao reagir com determinados agentes oxidantes, tais como, o Ferro, Oxigê-

\footnotetext{
* Enfermeira do Hospital Osvaldo Cruz, São Paulo.
} 
nio, derivados do Iodo e Água Oxigenada. Por ser uma enzima de fácil deteorização, deve ser sempre mantida em lugar fresco, seco, ventilado e protegido da luz. (MARTINDALE, 1982).

Atualmente, a papaína tem sido utilizada em áreas diversas, tais como: na indústria alimentícia (como amaciante de carne, na fabricação de queijos e nas cervejarias); nos laboratórios bacteriológicos e bioquímicos (na preparação de meios de cultura); na indústria de borracha e na farmacopéia (como antelmíntico, mucolítico e como auxiliar da digestão); utilizado para substituir a pepseria estomacal nos casos de dispepsia e indigestão ( ARNON, 1970; LASSOUDIÈRE, 1969; MEDINA et alii, 1980).

A utilização da papaína no tratamento de lesões de pele foi testada em estudos recentes. Christopher Rudge (1977), baseado em experiência anteriores com tribos sul-africanas, utilizou fatias de mamão verde como tratamento de uma deiscência cirúrgica, pós-transplante renal, que não respondera com antibioticoterapia tradicional, obtendo sucesso em poucas aplicações. Dias depois, vários jornais londrinos dedicaram extensas reportagens ao caso, afirmando que: "onde falharam os antibióticos, teve sucesso o remédio dos africanos". (MAMÃO, 1977).

O objetivo do estudo foi observar a evolução da cicatrização de soluções de continuidade com o uso da papaína.

\section{METODOLOGIA}

\subsection{População}

A população foi composta por 15 pacientes em lesões de pele do tipo solução de continuidade, sem serem consideradas características da lesão (etiologia, tamanho, local, presença de infecção) e do paciente (idade, sexo, estado nutricional, patologia), características estas que enfluenciam na cicatrização.

\subsection{Local}

O estudo foi realizado de 1983 à 1986 em dois hospitais da cidade de São Paulo (Hospital Osvaldo Cruz e Hospital Evaldo Fóz) e no posto de diagnóstico da Interclínicas no caso de um único paciente que fez o tratamento ambulatorial.

\subsection{Etapas do Trabalho}

\section{Autorização para iniciar o tratamento}

Esta autorização foi solicitada aos pacientes e à equipe médica responsável por eles.

A solicitação era precedida de explicação verbal sobre os objetivos do estudo e a ação da papaína, justificando seu uso baseado em estudos estrangeiros.

No início, não houve plena aceitação por parte da equipe médica e de enfermagem, ao contrário dos pacientes que se mostravam entusiasmados com a possibilidade de utilizarem um novo recurso no tratamento de suas lesões.

A parte prática do estudo teve início apenas quando um médico concedeu autorização, para aplicação deste novo tratamento, numa paciente com escara da região sacra que não apresentava sinais de melhora com os tratamentos utilizados até aquela data.

Após o sucesso obtido neste primeiro caso e nos subseqüentes, houve não só mais aceitação do novo tratamento por parte das colegas e da equipe médica, mas uma crescente solicitação do uso da papaína, por meio de prescrições médicas. Após isso, houve a implantação de uma rotina de curativo com o uso da enzima nos serviços de enfermagem dos dois hospitais anteriormente citados.

\section{Orientação da Equipe de Enfermagem}

A orientação foi feita individualmente pela autora às enfermeiras que prestavam assistência direta ao paciente submetido ao tratamento. Nos poucos casos em que a enfermeira não pudesse assumir a responsabilidade de fazer o curativo diariamente, a mesma orientação era dada ao auxiliar de enfermagem indicado por esta.

A orientação foi sendo feita oralmente, até a elaboração de um impresso contendo a técnica de curativo e algumas orientações simplificadas. Posteriormente, a autora do estudo foi convidada a proferir palestras junto a educação em serviço, para enfermeiros e, também, para a equipe médica.

\subsection{Técnica dos curativos com papaína}

$$
\begin{aligned}
& \text { Material: } \\
& \text { - água bidestilada estéril } \\
& \text { - papaína em pó } \\
& \text { - um pacote de curativo simples esterilizado } \\
& \text { - gazes esterilizadas e fita adesiva } \\
& \text { - recipiente esterilizado para diluição }
\end{aligned}
$$

\section{Procedimentos:}

- preparar a solução de papaína diluindo no recipiente, a água destilada com o pó da enzima na seguinte proporção: uma colher de café rasa da enzima para ca-' da 50 cc de água bidestilada.

- limpar a lesão utilizando gaze embebida na solução. A gaze deve ser aplicada energicamente, pois a ação mecãnica da gaze além de remover sujidades e secreções acumuladas, estimula o crescimento do tecido da granulação.

- cobrir a lesão com gaze embebida na solução de papaína, preenchendo com a gaze todos os contornos da lesão. Na presença de tecido necrosado, cobrir a área com fina camada da papaína em pó. No caso de cama- 
da espessa de necrose, faz-se a necrectomia (riscar a crosta com a ponta de um bisturi formando um desenho quadriculado) para facilitar a absorção da enzima, e então, cobri-lo com o pó e gaze úmida.

- proteger o curativo cobrindo-o com gaze seca e fixar com fita adesiva.

\section{Cuidados}

Deve-se evitar, na medida do possível, o contato da papaína com material metálico para evitar sua oxidação. Dar preferência a materiais de madeira, porcelana, vidro ou plástico.

Uma vez preparada a solução de papaína, deverá ser utilizada no menor espaço de tempo possível, pois uma vez diluída, a enzima perde sua estabilidade.

0 recipiente que guarda o pó da papaína deve ser opaco (para a proteção contra luz), bem fechado (para proteção da umidade do ar) e de tamanho pequeno (para evitar excessiva manipulação do pó).

\subsection{Técnica de curativo com mamão}

\section{Material:}

- recipiente esterilizado

- gazes esterilizadas

- um pacote de curativo simples esterilizado

- um mamão verde

- uma faca plástica esterilizada

- água destilada ou soro fisiológico esterilizado

\section{Procedimentos}

- limpar o mamão lavando-o, antes de abri-lo, com água e sabão retirando toda sujidade.

- cortar o mamão pela metada com faca plástica retirando as sementes.

- raspar a polpa do mamão, guardando o raspado no recipiente esterilizado.

- limpar a lesão utilizando gazes e água destilada ou soro fisiológico, limpar toda a lesão.

- aplicar o raspado no interior da lesão, cobrindo-a completamente com ele.

- proteger o curativo cobrindo-o com gaze seca e fixa com fita adesiva.

\section{Cuidados}

Evitar contato com mamão com materiais metálicos, devido a oxidação da papaína em contato com eles.

Após o mamão aberto, tomar os devidos cuidados para manter a polpa estéril, segurando a fruta pela casca durante sua manipulação.

0 mamão verde tem consistência endurecida, portanto, deve-se tomar cuidado ao preparar-se o raspado.

\subsection{Critérios de Avaliação}

Os critérios utilizados para avaliar a evolução das lesões, no decorrer do tratamento, foram os seguintes:

\section{Observação}

$\mathrm{Na}$ observação das lesões foi verificado: a cor do tecido comprometido e do tecido são ao seu redor; a presença ou não de tecido necrosado; o nível do comprometimento tecidual e de outras estruturas, como no caso de exposição óssea; a presença de secreção, suas características, quantidade e odor.

Esta observação foi feita em todos os casos antes da introdução do tratamento e à cada troca do curativo feito pela autora que nos primeiros casos foram feitos diariamente e depois a cada cinco dias.

\section{Mensuração}

Todas as lesões foram medidas em centímetros e na seguinte seqüência: comprimento $\times$ largura $\times$ profundidade (quadro).

Quando a profundidade da lesão foi menor ou igual a $2 \mathrm{~mm}$, foi considerado apenas seu comprimento e largura.

Foi feita a mensuração inicial, antes do início do tratamento, e a cada 5 dias durante sua evolução.

Todos os dados da observação e mensuração feitos pela autora foram registrados em fichas e documentados por fotografias.

\section{RESULTADOS E COMENTÁRIOS}

\subsection{Caracterização geral dos pacientes}

Os 15 pacientes submetidos ao estudo, apresentavam as seguintes características: (quadro em anexo)

- idade média: 41.8 anos, sendo o mais idoso com 76 anos e o mais jovem com 20 anos.

- sexo: masculino 9 pacientes e feminino 6 .

- patologia: 7 pacientes com AVC, sendo que 4 deles com quadro infeccioso associado apresentando hipertermia diariamente, sendo que destes 4,2 , apresentavam anemia. Outros 4 pacientes politraumatizados sendo que um deles com infecção pulmonar por Pseudomonas e em coma. Uma paciente com esclerose múltipla. Um paciente com CA de pele, diabetes e lesão decorrente de radioterapia. Um paciente paraplégico com infecção.

\subsection{Descrição da evolução das lesões}

Os pacientes apresentavam lesões de diâmetro variado, sendo a menor com 1,25 cm e, a maior, com 15,6 $\mathrm{cm}$. Nos 15 pacientes, das 24 lesões estudadas, 20 delas continham tecido necrosado.

0 primeiro paciente ( $n$. 1 do quadro) foi tratado com raspa de polpa de mamão verde, havendo cicatrização completa depois de 33 dias, de uma escara na região sacra, com $15 \mathrm{~cm}$ de comprimento, $8 \mathrm{~cm}$ de largura e 8,2 de profundidade.

A partir do segundo paciente, o mamão não foi mais utilizado por se julgar que este poderia of erecer riscos 
de infecção ao paciente, além de, apresentar dificuldades de ser manuseado. Passou-se, então, a se utilizar a papaína segundo a técnica descrita anteriormente na metodologia.

No início do tratamento, utilizando-se o mamão ou a papaína, observou-se um aumento da secreção de aspecto sero-purulenta, amolecimento do tecido necrosado, af rouxamento dos bordos e, conseqüentemente, pequeno aumento do diâmetro da lesão. (FIGURA 1).

Após a fase inicial, o tecido necrosado, já amolecido, foi sof rendo uma liquefação gradativa, até se desprender totalmente do tecido são.

À cada curativo, tentou-se retirar toda a secreção acumulada e o tecido necrosado desprendido durante a limpeza da lesão com gaze úmida.

Qualquer lesão tecidual que contenha exsudato purulento ou tecido necrosado depende de uma limpeza rigorosa, com remoção completa da crosta necrótica e do material infectado, para sua cicatrização. Esta limpeza, chamada desbridamento, pode ser feita mecanicamente, mas a técnica é cansativa, muito delicada e geralmente causa sofrimento ao paciente. Requer, também, muito cuidado para que, durante a sua execução, não venha a aumentar a contaminação local.

Atualmente, o debridamento com enzimas proteolíticas tem sido proposto para obter-se uma rápida remoção, não traumática, do material proteico não desejável nas lesões, apresentando a vantagem de não oferecer nenhum prejuízo ao paciente. (STARKOV, 1978; UDOD, 1981; WISEMAN, 1980).

Em 1978, STARKOV analisou as utilizações terapêuticas da papaína na medicina, segundo estudos realizados por ele no Instituto de Aperfeiçoamento Médico do Ministério de Saúde Pública da URSS. Em seu trabalho, $o$ autor justifica o uso da papaína em lesões de pele, devido a importante ação proteolítica e anti-inflamatória da enzima.

Segundo STARKOV (1978), a papaína reúne propriedades que permitem sua aplicação na recomposição dos tecidos necróticos, com a segurança de não danificar os elementos próprios do tecido sadio, ocorrendo assim, cicatrização rápida da lesão.

Em 1981, UDOD realizou um trabalho utilizando papaína em deiscências cirúrgicas e em lesões com necrose e infecção, utilizando o pó puro sobre as massas necróticas e solução de papaína nas áreas não necrosadas encontrando resultados positivos. 0 autor observou que a papaína abreviou a limpeza das feridas e das massas necróticas, facilitando a liquefação e retirada de secreção purulenta em todos os pacientes, ativando os processos de regeneração e abreviando os períodos de cicatrização. UDOD (1981) não observou, ainda, nenhum caso de recaída nem ef eitos colaterais locais ou gerais.

Durante este estudo, houve o receio de que a utilização de enzimas proteolíticas em feridas abertas pudesse provocar prejuízos do tecido sadio, uma vez que este é formado basicamente por proteína. Mas esse receio foi afastado ao tomarmos conhecimento de que, FLINDT (1978) fez referência em seu trabalho, da existência de uma antiprotease plasmática e alfa - um - anti-tripsina. A existência dessa substância no tecido sadio justifica a ação da papaína nos tecidos que não possuem esta antiprotease, tais como no tecido necrosado e nos microorganismos.

Toda solução de continuidade possui um alo de hiperemia ao seu redor, que poderá ter maior ou menor tamanho na dependência da gravidade da lesão, uma vez que esse alo reflete um sinal de inflamação local.

No decorrer deste trabalho observou-se de início, um aumento importante deste alo, chegando a duplicar seu diâmetro em alguns casos (pacientes 6, 10 e 12). $\mathrm{Na}$ maioria dos casos, a partir do 5 ? dia de uso da papaína, este alo retornou ao seu tamanho original regredindo gradativa e rapidamente.

WISEMAN (1980), indica a papaína como uma alternativa terapêutica no tratamento de lesões com processo inflamatório. Citando Rodeheaver, o autor afirma que quando uma lesão de pele necessitar de antibiotecoterapia local, a lesão deve ser tratada previamente em enzima proteolítica, pois a resposta inflamatória e um controle bacteriano mostram que a hidrólise enzimática dos coágulos da ferida aumentam significantemente a ação do antibiótico.

0 uso da papaína como debridante, anti-inflamatório e bactericida é citado por autores (STARKOV, 1978; UDOD, 1981) que afirmam que ela não danifica os tecidos sãos promovendo, assim, cicatrização rápida da lesão.

No decorrer do tratamento deste trabalho, após a fase de desbridamento da lesão pela papaína, observou-se diminuição progressiva da secreção e crescimento do tecido de granulação.

Esta fase caracterizou-se pelo aparecimento de uma borda de tecido cicatricial que foi aumentando de fora para dentro (FIGURA 2).

Caso haja indicação de enxerto de pele, ele será feito nesta fase. Entre os 15 pacientes estudados, apenas dois casos foram encaminhados para enxerto, para abreviar o tempo de cicatrização, após o preparo e limpeza da lesão com papaína (FIGURA 3).

Ainda nesta fase, observou-se que a cada troca de curativo ocorreu sangramento momentâneo da lesão após aplicação da gaze umedecida na solução. Isto ocorre devido à ação fibrinolítica da papaína. O sangramento cessa rapidamente pois o Ferro contido no sangue oxida a enzima, inativando-a (MARTINDALE, 1982).

Das 23 lesões estudadas, pode-se observar a cicatrização completa de 5, pois dos 15 pacientes acompanhados, 3 foram submetidos à enxerto de pele, 2 tiveram óbito, em 1 caso foi suspenso o tratamento e, 5 pacientes receberam alta hospitalar com suas lesões já em fase final de cicatrização.

Observou-se que na fase final da cicatrização das 
lesões estudadas quase não havia mais secreção, 0 alo hiperemiado ao redor dả lesão estava diminuído e o paciente referia prurido no local da lesão.

Dos 15 pacientes acompanhados, 12 eram conscientes e mantinham comunicação verbal. Com relação às sensações referidas por estes no decorrer do tratamento, observou-se que 6 não referiram, quando indagados, ardor durante o curativo ou após ele; 5 queixaram-se de ardor moderado durante o curativo e todos eles informaram que este ardor vai diminuindo gradativamente, durando, no máximo, 20 minutos até que cesse completamente.

Neste trabalho, não foi observado nenhum caso de reação alérgica à papaína ou qualquer outra reação indesejável. Apenas um paciente apresentou queixa de forte ardor durante alguns curativos, sendo suspenso o tratamento pela autora, apesar do médico responsável pelo paciente questionar a real necessidade da suspensão, por considerar estranho o fato do paciente não referir ardor em todos os curativos.

\section{CONCLUSÃO}

Levando-se em conta o objetivo para este trabalho, conclui-se que a papaína é um valioso recurso terapêutico no tratamento de lesões de pele, podendo ser utilizada pela enfermagem, com a segurança de não oferecer riscos ao paciente. Este estudo não preten- deu esgotar o tema. Por representar uma tecnologia apropriada ao nosso país, estimulou o início de uma pesquisa que vem se desenvolvendo na Universidade de São Paulo, onde se procurará utilizar um produto à base do mamão verde.

\section{REFERÊNCIAS BIBLIOGRÁFICAS}

1. ARNON, R. Papain Methods in enzymology. Academic Press, 19: 226-32, 1970

2. BALBACHAS, A. As plantas na medicina doméstica. 14. ed., São Paulo, Do Lar, s.d.

3. FLINDT, M. Health and safety aspects of working with enzymes. Process Biochemistry, (8): 3-7, 1978.

4. LASSOUDIĖRE, A. La papaine. Production, proprietés, utilization. Fruits, 24 (11/12): 503-17, 1969.

5. MAMÃO CICATRIZA? Veja, 27 de abril de 1977.

6. MARTINDALE, W.H. The Extra Pharmacopea. 28. ed. London, Pharmaceutical Press, 1982.

7. MEDINA, J.C. et alii. Mamão. São Paulo, Governo do Estado de São Paulo, ITAL, 1980.

8. ORGANIZACIÓN MUNDIAL DE LA SALUD. Extensión de cobertura baseada en las estrategias de atención primaria y participación de la comunidad. Washington, 1977 (Documentos Oficiales, 156).

9. STARKOV, G.L. et alii. Papain as a therapeutic enzyme in medicine. Klin Med., 56 (8): 189-122, 1978.

10. UDOD, V.M. et alii. Use of papain in treating suppurative post operative soft tissue complications and diseases. Khirrurgia, (5): 99-101, 1981.

11. WISEMAN. A. Topics in Enzyme and Fermentation Biotechnology. Chichester, Ellis Horwood Limited, 1980. 
ANEXO 1

QUADRO - Dados dos pacientes em estudo da mensuração das lesões com uso da papaína.

\begin{tabular}{|c|c|c|c|c|c|c|c|c|c|c|}
\hline \multicolumn{6}{|c|}{ Dados do Paciente } & \multicolumn{5}{|c|}{ Evolução das lesões } \\
\hline $\begin{array}{l}\text { código do } \\
\text { paciente }\end{array}$ & idade & sexo & patologia & $\begin{array}{l}\text { tipo } \\
\text { lesão }\end{array}$ & local & $\begin{array}{c}\text { tamanho } \\
\text { inicial }\end{array}$ & $\begin{array}{l}5 \stackrel{0}{9} \\
\text { dia }\end{array}$ & $\begin{array}{l}10^{\circ} \\
\text { dia }\end{array}$ & $\begin{array}{l}15^{\circ} \\
\text { dia }\end{array}$ & $\begin{array}{l}\text { final do } \\
\text { tratamento }\end{array}$ \\
\hline 1 & $44 \mathrm{a}$. & fem. & $\begin{array}{l}\text { AVC } \\
\text { anemia } \\
\text { desidratação }\end{array}$ & escara & sacra & $\begin{array}{l}15 \times 0,8 \times \\
8,2\end{array}$ & $\begin{array}{l}16,2 \times 09,1 \\
\times 8\end{array}$ & $\begin{array}{l}14,7 \times 7,0 \\
\times 7,4\end{array}$ & $\begin{array}{l}11,3 \times 6 \\
\times 5,9\end{array}$ & $\begin{array}{l}\text { alta no } 33{ }^{\circ} \\
\text { dia com } \\
\text { lesão } \\
1,0 \times 1,5\end{array}$ \\
\hline 2 & $55 \mathrm{a}$. & masc. & $\begin{array}{l}\text { AVA + dia- } \\
\text { betes + in- } \\
\text { fecção pul- } \\
\text { monar + úl- } \\
\text { cera gástrica }\end{array}$ & $\begin{array}{l}\text { necrose teci- } \\
\text { dual por ex- } \\
\text { travasamen- } \\
\text { to de } \\
\text { potássio }\end{array}$ & perna $E$ & $7,5 \times 25,5$ & inalterado & $\begin{array}{l}\text { inalterado } \\
\text { descolamen- } \\
\text { to da crosta } \\
\text { profundida- } \\
\text { de } 1,5 \text { dimi- } \\
\text { nuição qua- } \\
\text { dro clínico }\end{array}$ & $\begin{array}{l}\text { aumento te- } \\
\text { cido granula- } \\
\text { ção } 7,0 \times \\
24,8 \times 1,2\end{array}$ & $\begin{array}{l}\text { enxerto no } \\
29^{\circ} \text { dia }\end{array}$ \\
\hline 3 & $55 \mathrm{a}$. & masc. & $\begin{array}{l}\text { diabetes lin- } \\
\text { forragia na } \\
\text { lesão } \\
\text { CA de pele }\end{array}$ & $\begin{array}{l}\text { radiodermite } \\
\text { com linforra- } \\
\text { fia infectada }\end{array}$ & perna $\mathrm{D}$ & $\begin{array}{l}1,0 \times 1,5 \\
\times 0,8\end{array}$ & $\begin{array}{l}\text { tamanho } \\
\text { inalterado } \\
\text { diminuição } \\
\text { da secreção } \\
\text { linfática }\end{array}$ & $\begin{array}{l}\text { fim da lin- } \\
\text { forragia no } \\
6^{\circ} \text { dia } \\
\text { tamanho } \\
\text { inalterado }\end{array}$ & $\begin{array}{l}1,0 \times 1,3 \\
\times 0,5\end{array}$ & $\begin{array}{l}\text { cicatrização } \\
\text { no } 3^{\circ} \text { mês }\end{array}$ \\
\hline 4 & $64 \mathrm{a}$. & fem. & - & $\begin{array}{l}\text { furunculose } \\
\text { infectada }\end{array}$ & $\begin{array}{l}\text { região epi- } \\
\text { gástrica }\end{array}$ & $\begin{array}{l}2,6 \times 1,6 \\
\times 0,8\end{array}$ & $\begin{array}{l}2,2 \times 1,4 \\
\times 0,6\end{array}$ & $\begin{array}{l}1,8 \times 1,1 \\
\times 0,5\end{array}$ & $\begin{array}{l}0,8 \times 0,5 \\
\times 0,4\end{array}$ & 26 dias \\
\hline 5 & $76 a$. & masc. & $\begin{array}{l}\text { AVC + infec- } \\
\text { ção broonqui- } \\
\text { ca pseudo- } \\
\text { monas } \\
\text { anemia desi- } \\
\text { dratado }\end{array}$ & escaras & $\begin{array}{l}\text { sacra trocan- } \\
\text { ter D } \\
\text { trocanteer E } \\
\text { maleolo D } \\
\text { maleolo E }\end{array}$ & $\begin{array}{l}3,5 \times 2,0 \\
5,5 \times 4 \\
3,5 \times 2,8 \\
2,2 \times 2 \\
2,0 \times 1,8\end{array}$ & $\begin{array}{l}3,5 \times 2,2 \times \\
5,7 \times 4 \\
3,3 \times 2,7 \\
2,0 \times 1,7 \\
2,1 \times 1,7\end{array}$ & $\begin{aligned} & 80 \mathrm{~d}= 3,0 \times \\
& 1,6 \\
& 80 \mathrm{~d}= 4,7 \times \\
& 3,0 \\
& 80 \mathrm{~d}= 2,8 \times \\
& 1,8 \\
& 80 \mathrm{~d}= 1,4 \times \\
& 1,3 \\
& 80 \mathrm{~d}= 1,0 \times \\
& 0,9\end{aligned}$ & & $\begin{array}{l}\text { óbito no } \\
8^{\circ} \text { dia de } \\
\text { curativo }\end{array}$ \\
\hline 6 & $30 \mathrm{a}$. & fem. & $\begin{array}{l}\text { esclerose } \\
\text { múltipla }\end{array}$ & $\begin{array}{l}\text { úlcera com } \\
\text { tecido necro- } \\
\text { sado por } \\
\text { gesso } \\
\text { pelve podáli- } \\
\text { co em pele } \\
\text { enxertada }\end{array}$ & joelho E & $5,8 \times 4,6$ & $5,4 \times 4.2$ & $4,8 \times 3,7$ & $4,0 \times 2,8$ & $\begin{array}{l}\text { alta no } 18^{\circ} \\
\text { dia com } 3,2 \\
\times 1,9\end{array}$ \\
\hline 7 & $49 \mathrm{a}$. & masc. & $\begin{array}{l}\text { politraumati- } \\
\text { zado }\end{array}$ & escara & sacra & $\begin{array}{l}6,6 \times 5,2 \\
\times 1,2\end{array}$ & $\begin{array}{l}6,4 \times 5,0 \\
\times 1,2\end{array}$ & $\begin{array}{l}6,0 \times 4,2 \\
\times 0,5\end{array}$ & $\begin{array}{l}5,1 \times 3,6 \\
\times 0,3\end{array}$ & $\begin{array}{l}\text { alta no } 21^{\circ} \\
\text { dia com } 2,8 \\
\times 2,0\end{array}$ \\
\hline 8 & $49 \mathrm{a}$. & masc. & $\begin{array}{l}\text { paraplégico } \\
\text { infeç̧ão uri- } \\
\text { nária }\end{array}$ & escara & sacra & $\begin{array}{l}6,5 \times 5,0 \\
\times 4,8\end{array}$ & $\begin{array}{l}6,2 \times 4,8 \\
\times 4,8\end{array}$ & $\begin{array}{l}5,7 \times 4,2 \\
\times 4,0\end{array}$ & $\begin{array}{l}4,8 \times 4,0 \\
\times 3,5\end{array}$ & $\begin{array}{l}\text { enxerto no } \\
21^{\circ} \text { dia }\end{array}$ \\
\hline 9 & $62 a$. & fem. & $\begin{array}{l}\text { AVC } \\
\text { anemia } \\
\text { infecção } \\
\text { urinária }\end{array}$ & escara & $\begin{array}{l}\text { trocando D } \\
\text { halux D }\end{array}$ & $\begin{array}{l}2,5 \times 4,5 \\
4,0 \times 2,5\end{array}$ & $\begin{array}{l}2,2 \times 4,4 \\
3,7 \times 2,2\end{array}$ & $\begin{array}{l}1,8 \times 4,0 \\
3,3 \times 1,6\end{array}$ & $\begin{array}{l}1,2 \times 3,0 \\
3,0 \times 1,1\end{array}$ & \\
\hline 10 & $20 a$ & fem. & $\begin{array}{l}\text { politraumati- } \\
\text { zada }\end{array}$ & $\begin{array}{l}\text { lesão por } \\
\text { fratura ex- } \\
\text { posta de tí- } \\
\text { bia }\end{array}$ & perna $D$ & $\begin{array}{l}1,8 \times 1,4 \\
\times 0,7\end{array}$ & $\begin{array}{l}1,1 \times 1,0 \\
\times 0,2\end{array}$ & $0,4 \times 0,5$ & $\begin{array}{l}\text { cicatrizado } \\
\text { no } 14^{\circ} \text { dia }\end{array}$ & \\
\hline
\end{tabular}


QUADRO - Dados dos pacientes em estudo da mensuração das lesões com uso da papaína.

\begin{tabular}{|c|c|c|c|c|c|c|c|c|c|c|}
\hline \multicolumn{6}{|c|}{ Dados do Paciente } & \multicolumn{5}{|c|}{ Evolução das lesões } \\
\hline $\begin{array}{l}\text { código do } \\
\text { paciente }\end{array}$ & idade & sexo & patologia & $\begin{array}{l}\text { tipo } \\
\text { lesão }\end{array}$ & local & $\begin{array}{c}\text { tamanho } \\
\text { inicial }\end{array}$ & $\begin{array}{l}50 \\
\text { dia }\end{array}$ & $\begin{array}{l}10^{\circ} \\
\text { dia }\end{array}$ & $\begin{array}{l}15^{\circ} \\
\text { dia }\end{array}$ & $\begin{array}{l}\text { final do } \\
\text { tratamento }\end{array}$ \\
\hline 11 & $60 \mathrm{a}$. & masc. & $\begin{array}{l}\text { politraumati- } \\
\text { zado }\end{array}$ & $\begin{array}{l}\text { úlcera com } \\
\text { tecido necro- } \\
\text { sado gesso } \\
\text { coxo podáli- } \\
\text { do }\end{array}$ & perna e & $\begin{array}{l}8,2 \times 5,3 \\
\times 0,2\end{array}$ & $\begin{array}{l}8,0 \times 5,2 \\
\times 0,5\end{array}$ & $\begin{array}{l}7,2 \times 4,6 \\
\times 0,3\end{array}$ & $\begin{array}{l}\text { suspenso tra- } \\
\text { tamento por } \\
\text { queixa de } \\
\text { dor no } 13 \text { ? } \\
\text { dia com } 6,7 \\
\times \\
4,0 \times 0,1\end{array}$ & $\begin{array}{l}250 \text { dia com } \\
18,8 \times 12,2 \\
\times 3,8\end{array}$ \\
\hline 12 & $23 a$. & masc. & $\begin{array}{l}\text { politraumati- } \\
\text { zado com } \\
\text { perda de } \\
\text { massa ence- } \\
\text { fálica, em } \\
\text { coma } \\
\text { infecção }\end{array}$ & escara & sacra & $\begin{array}{l}16,2 \times 14,0 \\
\times 5,6\end{array}$ & $\begin{array}{l}18,1 \times 14,7 \\
\times 6,2\end{array}$ & $\begin{array}{l}18,5 \times 12,8 \\
\times 5,8\end{array}$ & $\begin{array}{l}18,0 \times 13,1 \\
\times 5,0\end{array}$ & $\begin{array}{l}35^{\circ} \text { dia com } \\
17,1 \times 13,0 \\
\times 3,2\end{array}$ \\
\hline 13 & $38 \mathrm{a}$. & masc. & $\begin{array}{l}\text { AVC } \\
\text { Anemia }\end{array}$ & escara & sacra & $\begin{array}{l}6,5 \times 5,2 \\
\times 2,0\end{array}$ & $\begin{array}{l}5,8 \times 5,0 \\
\times 1,8\end{array}$ & $\begin{array}{l}5,1 \times 4,2 \\
\times 1,5\end{array}$ & $\begin{array}{l}4,4 \times 3,7 \\
\times 1,0\end{array}$ & $\begin{array}{l}\text { alo cicatri- } \\
\text { cial com } 2 \\
\text { cm }\end{array}$ \\
\hline 14 & $49 \mathrm{a}$. & masc. & $\begin{array}{l}\text { AVC } \\
\text { infecção } \\
\text { urinária } \\
\text { infecção } \\
\text { pulmonar }\end{array}$ & escara & $\begin{array}{l}2 \text { sacras } \\
\text { maleolo D } \\
\text { trocanter D }\end{array}$ & $\begin{array}{l}\text { sacra I } \\
\text { com } 9,5 \times \\
9,0 \times 3,0 \\
\text { sacra II } \\
\text { com } 11,0 \times \\
6,8 \times 3,2 \\
\text { maleolo D } \\
\text { com } 2,1 \times \\
1,7 \\
\text { trocanter } \\
\text { D com } \\
3,5 \times 2,1\end{array}$ & $\begin{array}{ll}\text { sI: } & 9,3 \times \\
& 9,0 \times \\
& 3,0 \\
\text { sII: } & 10,7 \\
& \times 6,5 \\
& \times 3,0 \\
\text { mD: } & 2,0 \times \\
& 1,5 \\
& \\
\text { tD: } & 3,2 \times \\
& 2,0\end{array}$ & $\begin{array}{ll}\text { sI: } & 9,2 \times \\
& 8,5 \times \\
& 2,5 \\
\text { sII: } & 10,2 \\
& \times 6,0 \\
& \times 2,7 \\
\text { mD: } & 1,6 \times \\
& 1,0 \\
& \\
\text { tD: } & 3,0 \times \\
& 1,5\end{array}$ & $\begin{array}{c}\text { óbito } \\
\text { no } \\
12^{\circ} \text { dia }\end{array}$ & $\begin{array}{l}43^{\circ} \text { dia } \\
\text { enxerto }\end{array}$ \\
\hline 15 & $28 \mathrm{a}$. & masc. & AVC & $\begin{array}{l}\text { escara + } \\
\text { lesão } \\
\text { por tração } \\
\text { da sonda ve- } \\
\text { sical }\end{array}$ & pênis & $\begin{array}{l}1,2 \times 0,9 \\
0,5 \times 0,4\end{array}$ & $\begin{array}{l}0,7 \times 0,4 \\
\text { secou na } \\
3 \text { a aplicação }\end{array}$ & $\begin{array}{l}\text { secou no } \\
9{ }^{\circ} \text { dia de } \\
\text { aplicação }\end{array}$ & & $\begin{array}{l}\text { alta no } \\
28^{0} \text { dia } \\
\text { com } 3,5 \times \\
2,9 \times 0,3\end{array}$ \\
\hline
\end{tabular}




\section{ANEXO 2}

\section{FIGURA 1}

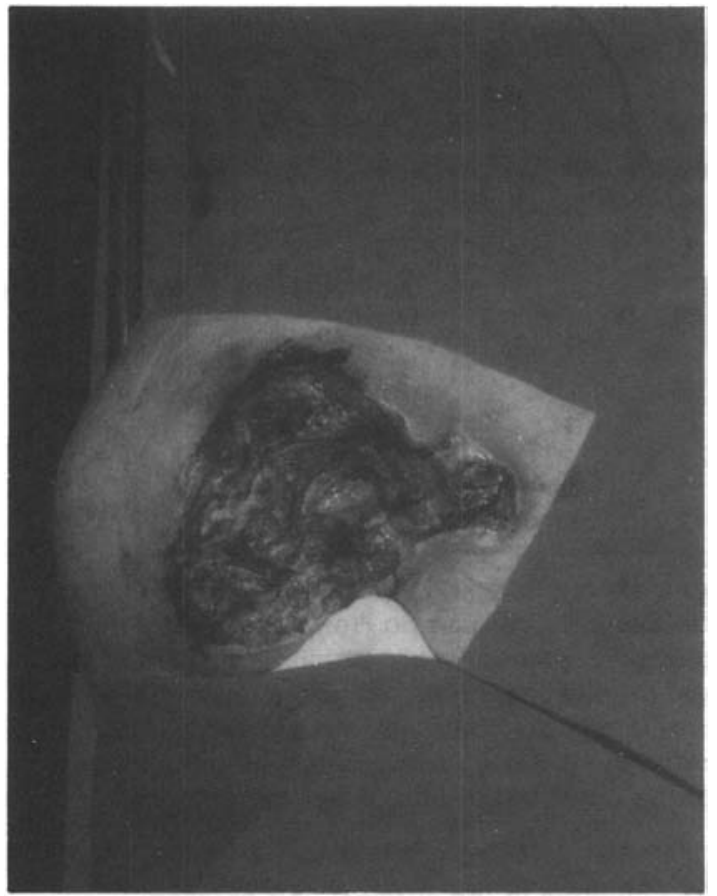

Antes do tratamento

\section{FIGURA 3}

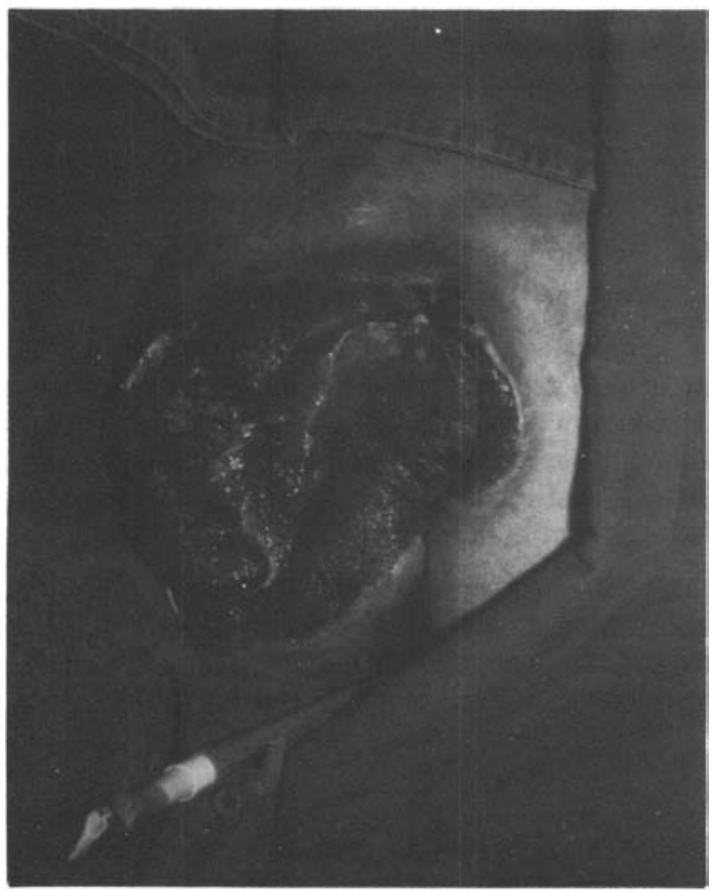

$15^{o}$ dia de uso
FIGURA 2

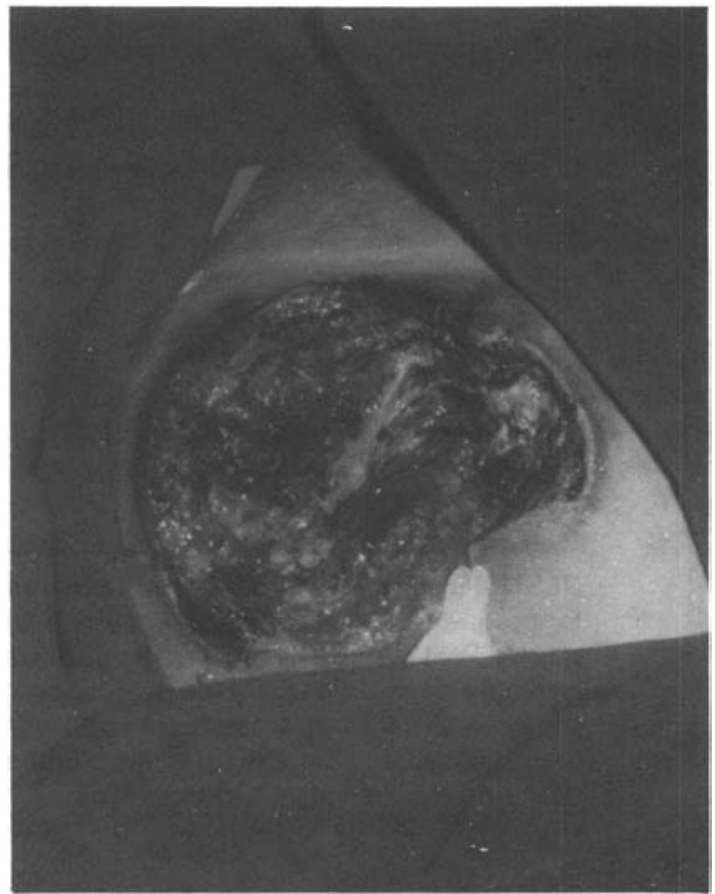

Quinto dia de uso

\section{FIGURA 4}

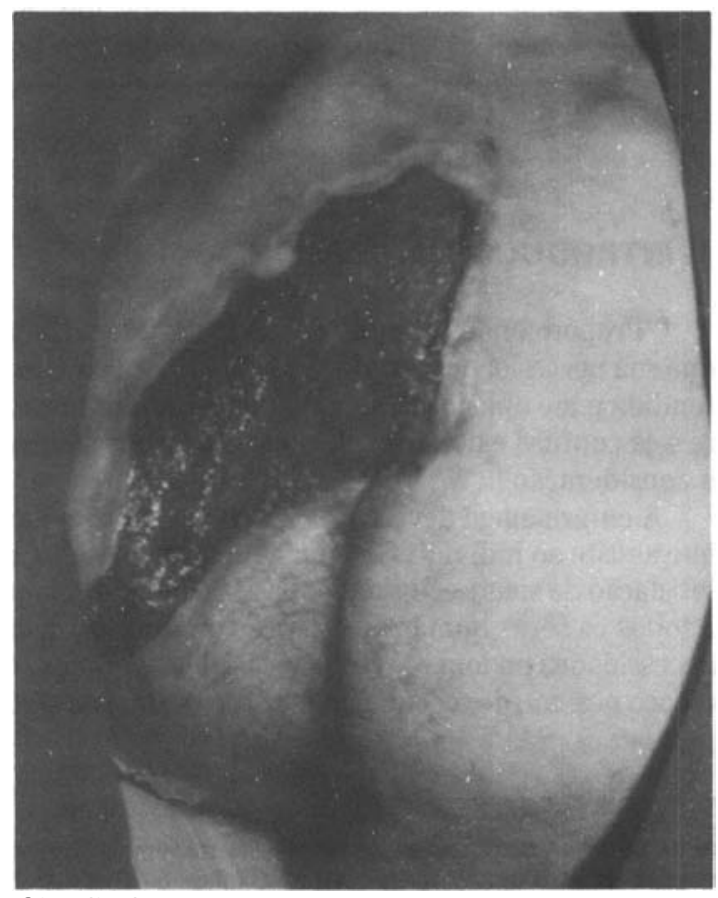

30 o dia de uso 